Perera, H.S.C., KJM, 2021, 10 (02)

\title{
Determinants of Financial Sustainability of the Microfinance Institutions in Sri Lanka
}

Perera, H.S.C.

Faculty of Management and Finance, Department of Management and Entrepreneurship, University of Ruhuna, Matara, Sri Lanka.

sunethrap@badm.ruh.ac.lk

\begin{abstract}
Today microfinance organizations are facing a challenge with how to balance poverty alleviation mission and sustainability. Hence, the importance of the sustainability of microfinance organizations goes beyond the poverty reduction mission. This research study was meant to determine the influential factors of financial sustainability in microfinance institutions in Sri Lanka. Existing two theories: Welfare Theory and Institutionalist theory were tested in MFIs in Sri Lanka with cause and effect relationship between variables, and the researcher adopted a cross-sectional research design with quantitative approach conducted in a field setting. Financial self-sufficiency is the dependent variable and twenty independent variables were used to test the determinant factors of sustainability. It was found that, the loan officer productivity, MFIs age, organization type, the yield on the gross loan portfolio, and profit margin have a positive and statistically strongly significance at $1 \%$ significant level. These factors profoundly affect the determination of the financial sustainability of MFIs in Sri Lanka. Further, the interest rate was positive with 5\% statistically significant level, and active borrowers were positive with $10 \%$ in determining the financial sustainability of MFIs. Operating expenses ratio and capital structure negatively affected with $1 \%$ statistically significant level, where portfolio risk at 30 days affected negatively at $5 \%$ in determining the financial sustainability. Moreover, other factors: average loan size, the percentage of female borrowers, MFIs size, cost per borrower, number of MFIs products, lending methodology, geographic locations, write off ratio, risk coverage ratio and MFI regulations did not have a significant impact on financial sustainability in Sri Lanka.
\end{abstract}

Keywords: Microfinance, Sustainability, Financial Self-sufficiency

Copyright: () 2021 Perera, H.S.C. This is an open access article distributed under the Creative Commons Attribution License, which permits unrestricted use, distribution, and reproduction in any medium, provided the original work is properly cited.

Correspondence: sunethrap@badm.ruh.ac.lk

ORCID of authors: Perera, H.S.C. - iD https//orcid.org/0000-0003-1839-0214

DOI: http://doi.org/10.4038/kjm.v10i2.7694 


\section{Introduction}

Microfinance programs are expanding opportunities in the financial market to the poor segment of the population, who are excluded by the formal and conventional financial services market. It has become an increasingly important component of strategies to reduce poverty or promote micro and small enterprise development. In many countries, especially in developing nations, the microfinance movement emerged in the 1970s while challenging the financial system by providing financial services to lowincome individuals and households. In general, microfinance institutions focus on providing credit to the poor who have no access to commercial banks. They focus on reducing poverty and help the poor with setting up their income generating business (Hermes et.al, 2011). Although the microfinance services have extensive development in recent years, the actual needs to the financial services in the poor communities are higher than the current needs and 2.7 billion people are estimated to have no access to formal financial services in the world (Marsden and Nileshwar, 2013). This shows a potential market for financially small projects and poor people who need to be addressed; proving that the initial objective of microfinance, which is outreach, is not well achieved (Nurmakhanova and Fedhil, 2015; Abdulai, 2016). This phenomenon is the core of the debate between welfare and financial sustainability approaches (Robinson 2001). The advocators of financial sustainability approach argue that outreach could expand while achieving financial sustainability. Financial sustainability is described as the ability of a MFI to cover all its costs from the revenue generated without ongoing subsidies (Nyamsogoro, 2010). Further, Nurmakhanva and Fedhil (2015) described that financial self-sufficiency would ensure sustainability of MFIs' operation and it will allow them to increase depth and breadth of outreach; subsequently being able to serve the poor segment of clients in larger scale in the long run. This will help MFIs to reduce the cost of a transaction, minimize the risk and also, achieve the primary objective of MFIs, which is to reach the poor (ibid, 2015).

On the other hand, the supporters of welfare approach argue that there is a trade-off between outreach and financial sustainability and that MFIs are targeting financial performance rather than the poor segment of the population (Hermes et.al.2011). It has been argued that unsustainable MFIs might help the poor now, but will not help them in the future because the existence of MFIs will be questionable without sustainability (Schreiner, 2000). The financial sustainability of microfinance institutions is a necessary condition for institutional sustainability (Logotri 2006, Nyamsogoro 2010). This illustrates that financial sustainability is crucial for a microfinance institution to serve the poor practically without donor support agencies. Today the process of scaling up or expansion of outreach poses a challenge to MFIs. MFIs' efforts to increase the scale while maintaining the financial sustainability is believed to result in a tendency to provide larger loans to the less poor clients and or a shift from rural to less rural clients. Hence throughout the world, financial sustainability of microfinance institutions is one of the issues that have recently been discussed by many researchers due to its importance in the livelihood development of the poor segment of the population (Kinde, 2012). Several studies have been conducted to measure the determinant of sustainability in microfinance institutions of various countries by using large and well-developed MFIs (Herms et.al, 2011; Rai and Rai, 2012; Kinde, 2010; Quayes, 2012; Tebulu, 2013; Kaur, 2014; Awaworyi and Marr, 2014; Nurmakhano, 2015; Chikaza, 2015; Heng, 2015; Yeshi, 2015; Ahmed and Bhuiyan, 2015). When the studies were compared, the level of significance of the factors influencing sustainability varied within them (Cull et al. 2007 cited in Tehulu, 2013). It shows that the factors affecting sustainability, their significance and their relationship with 
outreach is different from one economy to another and one study to another.

Further, when considering the relevant literature of Sri Lanka, only a few studies were conducted and these were mainly based on country-level case studies focused on overall microfinance sector analysis. Dissanayake $(2012,2014)$ has concluded that Sri Lankan microfinance institutions may attain profitability if those institutions can minimize the cost per borrower, operating expenses, write offs, and gearing. Especially the study conducted by Ahmed and Bhuiyan (2015) concluded that the majority of MFls in Sri Lanka are not financially sustainable, a limited number of them are profitable, and they are serving half of the market. The same study described that most of these MFls are operationally unsustainable and financially fragile. It is argued that the empirical evidences of the determinacies of financial sustainability remain unclear in Sri Lankan literature. Thus, the current research seeks to contribute to the literature to fill this gap of knowledge and it provides comprehensive evidence on determinacies of sustainability phenomena by using cross-country analysis.

This paper has been divided into seven sections. This section apart, section 2 is the literature review, section 3 is the methodology, section 4 is the data analysis and interpretation, section 5 is the conclusions, section 6 is the link to implications and section 7 is the contribution to knowledge and practice.

\section{Literature Review}

The financial sustainability of MFIs refers to the ability of MFIs to cover all the costs from its own generated income from its operations, without depending on external support or subsidy (Kinde, 2012). It was argued that unsustainable MFIs would not help the poor in the future because the MFIs have to disappear after the donor funds are finished (Schreiner, 2000, Gashayie and Singh, 2015). If MFIs can achieve their objectives without donner support, they are defined as financially sustainable (Kinde, 2012). It implies the ability of microfinance organizations to exist in the long run without subsidies while achieving their objectives. Financial sustainability is measured in two stages: operational sustainability and financial self-sufficiency (Quayes, 2012, Adhikary, 2014, Chikaga, 2015)). Irrespective of their subsidies if MFIs can cover their operational cost from their operational income, they are considered operationally sustainable (Meyer, 2002).

Moreover, if micro-finance organizations can cover both operating and financial costs and add another form of subsidy valued at market price from their own generated income, these MFIs are considered financially selfsufficient (Kinde, 2012). Khandker et al. (1995), has discussed financial sustainability with four related areas as economic viability, financial viability, institutional viability, and borrower viability. They further discussed economic viability as the economic cost of funds (opportunity cost) used for credits and all other operations with the income it generates from lending. Financial viability refers to, if at least MFIs can equate the cost per unit of currency lent, to the price it charges from its borrowers (interest rate). The MIX Market defines operational sustainability level of $110 \%$ or more as financial sustainability of MFIs, and the operational sustainability should have met the operational self-sufficiency of $100 \%$ or more (Rai and Rai 2012). The operational self-sufficiency measure is explained as; total financial revenue divided (/) financial expenses plus (+) operating expenses (Rai and Rai 2012). Researchers are arguing that there is a relationship between dependency ratio and financial sustainability; if that ratio is negative, one can argue those MFIs are financially sustainable. The dependency ratio is measured by the ratio of donated equity to total capital, and when it declines over the years in the MFI industry, it is an indication of the sustainability and profitability of MFIs (Kereta, 2007). Hence, numerous sources of capital such as loans, savings, deposits, and shares, could affect the profitability and 
sustainability of MFIs. Several studies have headed to determine the relationship between capital structure and sustainability. According to Kinde (2012) combination of various sources of capital of MFIs does not improve the financial sustainability and, if MFI is having more debt-financed compared to other sources of finance, they are deficient in their sustainability. Further, he argues that equity financing improves financial sustainability.

Moreover, microfinance was emerged to improve financial services to the poor by offering them small loans with no pledged collateral requirement; this process is called outreach. However, due to high demand today the process of outreach is required to emphasize financial sustainability, and the microfinance institutions putting all their efforts to increase social sustainability by providing various services (Outreach activities) to their clients while maintaining financial and operational sustainability. Bogan et.al (2007) studied the effect of capital structure on the financial sustainability of MFIs in East Asia, Latin America, Middle East, Africa, Eastern Europe, and South Asia and concluded that capital structure and financial instruments are critical determinants of financial sustainability. They found that the empirical evidence fails to support interpretations of the life cycle approach that focus on MFIs age as the deciding factor in sustainability. Ayayi and Sene (2010) studied financial sustainability with the variables such as productivity ratio, client outreach, the age of MFIs, good management, portfolio at risk, interest rate. They found that a high-quality credit portfolio coupled with the application of sufficiently high interest rates make a reasonable profit, and also good management are influential to financial sustainability. The study further concluded that the client outreach and age of microfinance institute has positive but lesser impact on attainment of financial sustainability and the percentage of women borrowers is a non-significant and has an adverse effect.
Rai and Rai (2012) investigated the financial sustainability of MFIs with eight independent variables: Number of active borrowers, portfolio at risk 30 days, women borrowers, debt-equity ratio, Inception of firm, capital/assets ratio, operating expenses /loan portfolio, and concluded that capital/assets ratio, operating expenses /loan portfolio and portfolio at risk 30 days are the main factors which affected the sustainability of MFIs. Kinde (2012) empirically tested the financial sustainability of microfinance institutions in Ethiopia and study has used MIX market definition to measure financial sustainability (FSS $=$ Adjusted Revenue/Adjusted Expenses). It is said that those MFIs are financially sustainable if FSS centered around 1 or more. Study come up with the conclusion that breadth of outreach, depth of outreach, cost per borrower, and the dependency ratio was significantly affected by the financial sustainability of MFIs in Ethiopia. However, staff productivity and capital structure have an insignificant impact on financial sustainability. Also, it proposes further studies with ownership, age, geographical locations, growth stages, dimensions of sustainability. Tehulu (2013) has empirically tested the effect of seven determinants on the financial sustainability of MFIs in East Africa. It describes those seven determinants as Breadth of outreach, deposit mobilization, management inefficiencies, portfolio at risk, loans intensity, and loan size. It was concluded that there is a positive relationship in loan intensity and loan size with financial sustainability. Also, management inefficiency and portfolio at risk has a negative relationship while the breadth of outreach and deposit mobilization is not affected by the sustainability of MFIs. Marakkath (2014), empirically tested sustainability of Indian microfinance institutions with mix method approach and concluded that growth factor, portfolio risk factor, development factor and institutional factor were identified as factors affecting the operational self-sufficiency of Indian MFIs. Also, it was identified cost efficiency factor was the factor discriminating its operational 
self-sufficiency status. Gashayie and Singh (2015) have conducted a literature review on factors that affected the financial sustainability of microfinance institutions. Based on the current literature, the study proposed a comprehensive framework which provided possible potential factors that affect the financial sustainability of microfinance institutions. Accordingly three major factors were affected to financial sustainability; MFI related factors (breadth, depth, deposit mobilization, management efficiency, Staff Productivity, portfolio risk, loan intensity, size, age, capital structure, yield, operating expenses to long portfolio ), macroeconomics related factors ( per capita income, interest rate, completion and degree of economic freedom) and borrower related factors(cost per borrower, number of active borrowers , women borrowers and group lending). Dissanayake (2014) concluded that cost per borrower is a determinant for return on equity and operational self-sufficiency. Besides, the operating expense ratio and write off ratios are determinants of return on equity, return on assets and profit margin. Where, Thrikawala (2017) discussed the gender diversity influence the operational sustainability of MFIs in Sri Lanka. It was found that positive impact on the microfinance industry to gender diversity, female CEOs and female chairpersons have a positive effect on operational sustainability.

\section{Poverty Approach to Microfinance (Welfare Theory)}

Many pieces of research describe poverty approach as a welfare approach and it can be measured by the number of active clients who received the loans, including a large number of indigent clients who need the financial services (Brau and Woller, 2004; Robinson, 2001; Meyer, 2012; Arun, 2005; Chikaza, 2015). The empowerment of marginalized people who are economically active and by giving them priority concerning financial services is one of the main aims of this approach. Hence, researchers argued that even when it is not profitable, MFIs need to serve as many poor people as possible
(Chikaza, 2015). Woller (1999) argued that donors, government and social investors should support the deficit in operation. The welfare approach wants to reach many poor people, to achieve a social goal to reduce poverty regardless of using subsidies. This approach focus on the social impact and the investors are not worried about the profits (Morduch, 2000). Therefore, assessments of the microfinance institute are not based on the profitability of the institution but the social merit of the program (Brau, 2004). The poverty approach to microfinance or the welfare theory argues that there is a trade-off between reaching to the poor (outreach) and the financial sustainability because it is mainly supported by donors to improve the quality of life and the wellbeing of the poor ( Chikaza, 2015; Meyer, 2012). In most countries MFIs operate as non-profit organizations to extend credit to the poor and facilitate the alleviation of poverty; but some MFIs operate based on profit maximization without sustainability, deviating from the goal of outreach to the poor (Quayes, 2015). There has been a paradigm shift in the microcredit industry from subsidized credit delivery programs to sustainable commercial microfinance over the last decade (ibid, p1911).

\section{Self-Sustainability (Institutionalists' theory)}

Approach

Researches described this approach as institutionalists' theory and argued that this approach is the only way to support the poor while creating financial self-sufficiency within MFIs. (Woller 1999, Bray and Woller 2004). In this approach, it is expected that financial sufficiency is to be achieved and the MFIs can cover all the costs using interest charged on the loans. Therefore MFIs need to make a profit from their operations since on investments from donors may be used up closing the MFIs in the future (CGAP, 2003; Chikaza, 2015). Porwal (2001) showed that financial sustainability is needed to build solid instructions that can provide financial services for an extended period. The supporters of the self- sustainability approach 
argued that donor dependence is not certain and the in the long run MFIs should go for innovations that reduce the cost of supply. As a result, all MFIs and the microcredit industry, in general, are faced with the reality that policymakers, donors and investors are increasingly emphasizing financial performance by eliminating the reliance on subsidies (Quayes 2015).

Quayes (2015) further highlighted that the motivation for such an emphasis on financial performance stems primarily from the apprehension about the uncertainty of future cash flow of funds from MFIs, which currently thrive on subsidies. With this selfsustainability approach, MFIs should have to continue their operations without risk of any reduction of their loan portfolio. Also, MFIs should understand that donor agencies will continue participation, supply funds over the long run and they expect efficient utilization of their funds (Quayes 2015). Thereby financial sustainability should allow the MFIs to compete with traditional financial intermediaries, allowing them to diversify their assets liability portfolio and also have access to sources of funds from deposits (Ibid, page 911). Sathye et al., (2014) discussed that the financial sustainability of MFIs is essential if it is to continue providing services to their poor clientele (outreach). However, many researchers argued that outreach needs to be achieved without losing sight of sustainability (Meyer and Seller 2002, Kereta 2007, Sathye et.al.2014). This concept of sustainability of microfinance can divide into four interrelated sustainability's such as financial, economic, institutional, and borrowers' viability (Khandker et.ai 1995, Rai and Rai, 2012). They further discussed that financial viability relates to the fact that a lending institution should at least equate the cost spent on clients with the price they charge from their clients (for example interest rates that MFIs charge from clients) (Rai and Rai, 2012). Economic viability relates to meeting the economic cost of funds (opportunity cost), used for credit and other operations with the income it generates from its lending activities (Ibid, page 2). It shows that financial sustainability helps microfinance institutions to service the poor more effectively.

In summary, the sustainability paradigm is underpinning the traditional subsidized credit programs of 1960 - 1970 periods, due to the large unavailability of institutions (Robinson, 2001). Researchers explained poverty arises partly because of the absence of economic opportunities and microfinance is considered as a sustainable path to provide a viable economic alternative to the poor population (Abdulai, 2016). Hence, the importance of the sustainability of microfinance organizations goes beyond the poverty reduction mission. Many researchers pointed out that based on the social impact and good governance viewpoint, the subsidized program was challengeable and had less success in most of the developing nations (ibid p147). Also, the researchers pointed out that institutional sustainability is essential to deliver financial services to poor clients without subsidies. Hence, the sustainability of microfinance institutions remains an integral and critical debatable area of microfinance research. This research is the modest attempt to fill this knowledge gap by empirically analysing the factors affecting to the sustainability of MFIs in Sri Lanka.

\section{Research Methodology}

In this research, the applicability of existing theories was tested in MFIs in Sri Lanka with cause and effect relationship between variables, and researcher adopted a crosssectional research design with quantitative approach conducted in a field setting. The study is theory testing research; consequently, internal validity is of great concern. Internal validity refers to whether the study is robust enough to infer causal relationships between the variables (Cook and Campbell 1979). Cross-sectional designs in natural settings are weak designs concerning theory testing; this is because researchers cannot manipulate independent variables and control for the confounding factors. The study makes use of panel data 
model to explain the relationship between dependent and independent (explanatory) variables. Panel data or longitudinal data constitute of cross-sectional data collected from the same individuals or organizations, repeatedly observed from the same MFIs collected over a number of periods (Johnson and Dinardo, 2007). The heterogeneity of the data explicitly considered of panel data, and their MFIs specific variables were estimated separately. Variable separation was significant in this study because this study means to establish relationships between dependent and independent variables with a specific focus on individual specific characteristics of MFIs in Sri Lanka. Further, the panel data model was selected because the measured effects directly cannot be detected through pure cross-section or time series data. The panel data model provided less collinearity among variables, more degree of freedom and more informative data with variability (Nyamsogoro, 2010). The general panel data regression model used as Yit $=\alpha i+\beta^{\prime} X_{i t}+\sum$ it.

As per the objective, and based on the basic conceptual model $\left(Y=\alpha i+\beta^{\prime} X i t+\sum i t\right)$, the empirical findings from the econometric results on the factors affecting the financial sustainability of Sri Lankan microfinance institutions are described with the following operational model;

$\mathrm{FSS}=\alpha \mathrm{i}+\beta_{1}$ capstruc $_{\mathrm{it}}+\beta_{2}$ intrate $_{\mathrm{it}}+\beta_{3}$ aveloans $_{i t}+\beta_{4} \quad$ loanofiprodu $u_{i t}+\beta_{5}$ actborrowers $_{i t}+\beta_{6}$ femaleborrw $+\beta_{7}$ mfiage $_{i t}$ $+\beta_{8}$ mfisize it $+\beta_{9}$ portforisk it $+\beta_{10}$ costpeborrow it $+\beta_{11}$ mfitype it $+\beta_{12}$ mfiproducts $_{\mathrm{it}}+\beta_{13}$ mfilenmeth it $+\beta_{14}$ mfigeoloc it $+\beta_{15}$ operaexratio it $+\beta \quad 16$ yieongrpolio it $+\beta_{17}$ wriofratio $_{i t}+\beta_{18}$ riskcovratio $_{\text {it }}+\beta_{19}$ mfireg $_{i t}+\beta_{20}$ profmarg $_{i t}+\Sigma$ it

Where FSS, the dependent variable is the financial self-sufficiency, $\alpha \mathrm{i}$ is a constant term, $\beta \mathrm{i}$ measures the partial effect of independent or explanatory variables in the period of $\mathrm{t}$ for the unit $\mathrm{i}$ (MFI), Xit is the independent variables as described in Table 1 and $\Sigma_{\mathrm{it}}$ is the error term. The variables, both dependent and independent, are for crosssection unit $i$ at time $t$, where $i=$ MFIs ( 1 to n) and $t=1$ to 5 .

\section{Operationalization of Variables and Variable Description for the Determinacy of Financial Sustainability}

This section describes the variable description used as dependent and independent (explanatory) variables of the determinacies of financial sustainability in microfinance institutes in Sri Lanka. Table 1 summarizes the dependent and independent variables and their definitions, variable name in the regression model, measurement indicators, and expected relationship on determinacies of FSS used for analysis of the MFIs in Sri Lanka.

\section{Population and sampling strategy}

For the data collection in Sri Lanka, the target population of the study is all 67 microfinance institutions that provide financial services (Lanka Microfinance Practitioners' Association, 2012- 2017). Microfinance institutions that were included in the sample are formal microfinance institutions which have five or more years of existence as a microfinance institution in Sri Lanka and the sample included 43 MFLs. The study consists with data on financial sustainability information for the period of 2012-2017 of MFIs in Sri Lanka. To construct the data set for the study the objective was obtaining a panel (cross-section and time series) of data over as many years as possible, at least for five consecutive years. Construction of data set however will be limited by the availability of the recorded information in the MFIs. However, as much as possible the researcher will cross-check the data through key informant methodology.

\section{Data Collection}

In the study, the level of analysis is the business practices, while the level of data collection is the microfinance institutes. 
Below, the researcher discusses factors related to one-sided data versus dyadic data. The study also offers several arguments for adopting a microfinance institutions perspective as a supplier's perspective. In the study, the researcher aims to examine suppliers' perceptions regarding several variables. The researcher acknowledges that these perceptions are naturally influenced by their business environment, their position in the Sri Lankan market, and the value chain for microfinance business practices as well as the financial industry. Microfinance institutions in Sri Lanka are likely to have different perceptions of the same issues, influenced by their specific environment and position in the industry and the markets. The purpose of this research is therefore not to identify "objective realities" in these business practices, but to get insights into microfinance institutions' perceptions. Thus, concerning the choice of collecting data, only on the micro-finance institution' side was considered.

The data collection was done mainly through secondary sources, but where necessary, when the secondary sources are lacking, primary sources were used to collect the information. When collecting the information from MFIs in Sri Lanka, most of the data was created by the researcher based on multiple sources. Microfinance Information Exchange (MIX) market data based from 2012 to 2017 of MFIs in Sri Lanka was used as one of the primary and secondary sources. The data published by Lanka Microfinance Practitioners Association, Microfinance review Sri Lanka: Performance and analysis reports from 2012 to 2017 were used to collect the missing data from MIX market data, on sustainability of MFIs in Sri Lanka. The researcher also used annual reports published by MFIs for more information and verification. Furthermore, in case of discrepancies and missing information, organizations were contacted via telephone for clarifications. All organizations contacted have positively responded for information verification. Some of the organization's data which were not published were collected through Key informant methodology by visiting those organizations. Pre-study was conducted to investigate the business practices of microfinance institutional setting and to determine the relevant issues in the selected critical variables of the study. Seven interviews with the managers of microfinance institutes and ten interviews with the clients of microfinance institutes were organized

\section{Data Analysis Strategy}

The panel / longitudinal research design was adopted. The collected panel data was analyzed from both descriptive and inferential statistics such as regression and correlation. The descriptive statistics included the mean and the standard deviation. The correlation analysis was used to establish the relationship among variables, and multiple regression method was used to analyze the panel data. Collated data from MFIs were rearranged, sorted, and organized without harming them and entered in an Excel sheet before analyzing them with STATA econometric software. The STATA software has a range of advanced tools for panel data analysis, and it helps researchers to analyze panel research data effectively and efficiently (Baum, 2006). STATA is userfriendly software, and it has online technical support and learning resources; thereby, implementing panel data is quite easy, and convenient (Gujarat, 2003). In the analysis, the researcher first compares the statically analyzed data with the available literature and its relevancy with MFIs in Sri Lanka.

\section{Data Analysis and Interpretation}

The financial sustainability (FSS) is the dependent variable, described as an ability of MFIs to cover all its cost from its own generated income through its operations without depending on external support funding. It is a ratio of adjusted financial revenue to operating expenses + financial expenses +loan loss provisions expenses and expenses adjustments. When the ratio is 
above 1 , it describes that such MFIs are financially sustainable and when it is below 1 , it indicates that such MFIs do not have an ability to pay their expenses from their generated income (Nyamsogoro, 2010). Table 2 illustrates the descriptive statistics values of FSS of MFIs

According to Table 2 the mean value of FSS is 1.199527, it indicated that Sri Lankan MFIs are financially sustainable. The standard deviation for this value is .2889168 , and this is a value of the existence of dispersion in the sustainability of studied MFIs in Sri Lanka. In total, the study covered 204 observations: out of these observations $186(86.5 \%)$ indicated as sustainable and from these 186 observations $72(38.7 \%)$ are NGO's. It shows that most of the sustainable MFIs in Sri Lanka are non-NGOs

\section{Descriptive Results of Independent Variables and Financial Sustainability}

Independent variable includes capital structure, interest rates, average loan size, loan officer productivity ratio, number of active borrowers, percentage of female borrowers, MFIs' age, MFIs' size, cost per borrower, organization type, MFIs' products, lending methodology of MFI, geographic location of MFI, operating expenses ratio, yield on gross loan portfolio (real), write off ratio, risk coverage ratio, MFIs' regulations, and portfolio risk at 30 days. In the chapter three of this study, these variables were described in detail. Table 3 illustrates the descriptive statistical results of the independent variables described in the model, their mean values and the values of standard deviation. Accordingly, it includes twenty institutional factors mentioned above, including all outreach factors that effect to determine the financial sustainability of MFI in Sri Lanka.

\section{Econometric Results and the Determinants of Financial Sustainability}

Based on the model describe in the methodology the study presents the econometric results on the determinants of sustainability of the microfinance institutes in Sri Lanka. First, it explains the model summary; second, it describes the model fitness for the determinants through twenty variables including all outreach variables with the financial sustainability of MFIs in Sri Lanka. Table 4 explains the model summary of the model.

Table 4 describes $\mathrm{R}^{\wedge} 2$ as $47.9 \%$ (.497), suggests that the proportion of variance in the dependent variable which can be explained by the independent variable. This figure indicated that $52.1 \%(.521)$ of the variation in the dependent variable is not explained by the independent variables of the model " $b$ ". This could imply average explanatory power. However, for the panel data $\mathrm{R}^{\wedge} 2$ is above 0.2 is still large enough for a reliable conclusion (Ganka, 2010; Kinde, 2012; Nyamsogoro, 2010).

In Table 5 illustrates the model fitness of the model which is relevant to the determinant factors of sustainability. It describes that the model is statistically significant at $1 \%$ significant level.

The econometric values of independent variables with its financial sustainability (dependent variable) are described in Table 6 and the multi-co-linearity was tested among those values are with VIF. Table 6 illustrates the VIF factor varies 1.451 to 5.150 and it is depicted that low multi-collinearity among the variables. This value is in the acceptable level (VIF < 10).

Capital structure is described as the various sources of capital, included in the composition of the capital of MFIs. Capital structure refers to the amount of debt or equity employed by MFIs to fund their operations and other assets. This variable was described in under the conceptualization in more detail. Table 6 indicated that this variable has negative, strongly statistically significant at 1 percent significant level. This result implies that the combination of the various capital of MFIs does not improve the 
financial sustainability of MFIs in Sri Lanka. Further, the negative coefficient (-.331) indicated that most MFIs are debt-financed compare to the other sources of finance; more debt cause the sustainability to decrease. In other words, equity finance improves their sustainability. This finding confirms with the findings of Kinde (2012), that financial sustainability is negatively affected by higher debt capital of MFIs in Ethiopia. Interest rates and its income made from MFIs operations are the primary revenue source; hence, interest income is one of the significant variables that affect the financial sustainability. However, it was found that with other firm-level variables the coefficient is .154 and statistically significant at $5 \%$ significant level. This finding is in line with the findings of Nyamsogoro (2010); financial sustainability is strongly associated with higher interest rates. Nevertheless, the literature review in the study described that higher interest rates cause a decrease in reaching the poor clients and it may lead to mission drift. The mean value of Sri Lankan MFIs is in moderate level (20\%) when compared to the other well-established commercial banks in Sri Lanka. Average loan size also affects to determine the financial sustainability of MFIs and Kinde (2012). According to the Table 6 coefficient for the average loan size, .025 is positive and statistically not significant (standardized coefficient beta is .717) even at $10 \%$ significant level. The results indicated that average loan size has some association with financial sustainability, but it is not in a statistically significant level. Hence, it can be concluded that the average loan size does not significantly impacted to decrease or increase the financial sustainability of MFIs in Sri Lanka. This finding confirms the finding of Chikaza (2015). Loan officer productivity ratio is the ratio of the number of active borrowers served by the number of loan officers (CGAP, 2003). It assumes that, where all other variables are constant, when the number of clients served increases the productivity of loan officer will also increase (Ayayi and Sene, 2010). According to the Table 6 , the coefficient of this variable is positive (.230) and strongly significant at $1 \%$ statistically significant level in MFIs in Sri Lanka, and it shows loan officer productivity greatly affected to increase the sustainability of MFIs. Further, this shows that loan officers are helping MFIs to increase their number of clients and granting microcredits to poor people with their positive actions. This finding confirms the finding of Ayayi and Sene (2010) and Dissanayake (2012).

The number of active borrowers is an indication of more breadth of outreach, and the econometric results of the variable are positive (.151) and statistically significant at $10 \%$ (, 077) significant level. The results describe that increased number of borrowers cause to increase the volume of sales of MFIs and in return MFIs become financially sustainable. Because when the numbers of borrowers increase, MFIs will be able to reduce the cost per borrower and it will lead to getting economies of scale as well as sustainability. It can be concluded that the active number of borrowers positively contributed to determining the financial sustainability of MFIs in Sri Lanka.

Percentage of female borrowers are a significant indirect proxy to measure the breadth, and the Table 6 pointed out that percentage of female borrowers are positive (.026) and statistically insignificant even at $10 \%$ significant level. This result indicated that though the coefficient is a positive, percentage of female borrowers do not affect when determining the financial sustainability of MFIs in Sri Lanka.

MFIs' age shows the length of service or the existence of the MFI in microfinance industry and the coefficient of this variable is positive (.277) and statistically strongly significant at $1 \%$ significant level. The results imply that the experienced MFIs are more sustainable in the microfinance industry in Sri Lanka and it seems that most MFIs use effective credit management and risk management techniques to exist in the industry for a long period. Also, experience increases the productivity of the services to 
clients, and this leads to higher financial sustainability. The study can conclude that age of MFIs in Sri Lanka heavily impacted when determining the financial sustainability. These results were confirmed by the results of Bogan (2009); Mersland and Strom (2007); Cull et al. (2008); and Nurmakhano et al. (2008).

MFIs' size can be measured by the value of their assets (Mersland and Strom, 2009). The coefficient of the size of MFI is positive (.068) and statistically insignificant (.432) even at $10 \%$ significant level. This result is contradicting the finding of Mersland and Strom (2009); Bogan (2012); Nurmkhano et al. (2015); and Nyamsogoro (2010). The study concluded that the size of MFIs has a positive coefficient, but it does not significantly affect in the determination of financial sustainability of MFIs in Sri Lanka. Cost per borrower is the cost that MFIs are expending to maintain a client. The total cost involves acquiring and serving their borrowers, which highly affected the efficiency and effectiveness of MFIs. These costs included administrative expenses, financial expenses, and staff or personal related expenses, etc. Hence, lower the cost per borrower, the MFI can improve productivity and it leads to improving the financial sustainability. Cost per borrower is calculated by dividing all operating expenses by the average number of active borrowers. The coefficient of this variable is negative ($.013)$ and statistically not significant (.840) even at $10 \%$ significant level. This result pointed out that though the coefficient of the cost of the borrower is positive and it does not affect in determining the financial sustainability of MFIs in Sri Lanka. This result is confirmed by the findings of Chikaza (2015) and Dissanayake $(2012,2014)$.

Organization type can be described based on the MFIs ownership structure. Organization type of Sri Lanka can be categorized under nine major headings mentioned above and agreed that most of MFIs in Sri Lanka belongs to limited liability companies. The econometric results show that it is positive
(.221) and statistically strongly significant at $1 \%$ significant level. This result proves that the organization type has impacted immensely to increase financial sustainability. Hence, it can be concluded, the type of the organization is one of the major determinant factors of financial sustainability of Sri Lankan MFIs. This result is in line with Mersland and Strom (2009); and Nurmakhono et al. (2015) but the results are contradicted with the results of Nyamsogoro, (2010).

The number of MFIs' products affects sustainability. Most of MFIs in Sri Lanka offer loans, savings products, and other services to their clients. Further, around $76 \%$ belongs to this category. The coefficient of this variable is positive (.030) but statistically insignificant even at $10 \%$ significant level. This finding is not in line with microfinance literature which describes that increased number of products in microfinance organizations cause to improve the financial sustainability (Navajas et al., 2000). The positive coefficient indicated that, even though microfinance institutes in Sri Lanka offer different kinds of products to their clients, it does not significantly affect when determining financial sustainability.

The lending methodology of MFIs is described as the ways of delivery mechanism of their services to their clients, and this refers to the loan delivery mechanism. The econometric results of this variable shows that the coefficient is positive (.064) but statistically insignificant (.486) even at $10 \%$ significant level. The $65 \%$ of MFIs in Sri Lanka's lending structure focus on individual loans, $21 \%$ focus on individual based solidarity groups and all other methods comply only $14 \%$ (group and individual lending $8 \%$, individual through clusters and $2 \%$ individual loan through CBO). The study concluded that though the coefficient indicated is positive, the lending methodology does not affect to determine the financial sustainability of MFIs in Sri Lanka. 
The number of geographic locations of MFIs refers to the areas of operation. In Sri Lanka all MFIs are in rural areas. Around $23 \%$ of MFIs serve both rural and urban areas. In the econometric results the coefficient indicated is positive (.060) and statistically not significant (.524). This result confirms the results of Woller, (2000); Navajas et al. (2000) and Nyamsogoro (2010) (only for the Central zone in Tanzania). The study can conclude that, although the coefficient is positive the geographic location does not significantly affect to determine the financial sustainability of MFIs.

Operating expenses ratio described above mention that the total operating cost to outstanding loan portfolio could negatively affect the sustainability of MFIs. It is one of the ways to measure the management efficiency of MFIs (CGAP, 2003). The efficiency leads to cost reduction strategy for MFIs, and it will positively contribute to financial sustainability. The results indicated that it is negative (-.470) and strongly statistically significant at $1 \%$ significant level. This result shows that operating expenses ratio heavily affects to decrease the financial sustainability. These expenses include all administrative and staff expenses of MFIs (CGAP, 2003). It is agreed that operating costs are high when lending to poor clients; also, researchers pointed out that higher ratio of operating cost per average gross loan portfolio, implies better outreach and lower the financial sustainability (Yeshi, 2015). When comparing the results of MFIs in Sri Lanka, operating expenses ratio negatively affected to determine the financial sustainability. This finding confirms the findings of Dissanayake (2012); Yeshi (2015); Millson (2013); Nyamsogoro (2010); and Rai and Rai (2012).

The yield on gross loan portfolio, as mention above, is the proxy to measure interest rates charged by microfinance institutions from the loans of their clients (Yeshi, 2015). The coefficient of this variable is positive (.248) and strongly statistically significant at $1 \%$ significant level. The results imply that when the yield on gross loan portfolio increases the financial sustainability will increase. Hence, it can be concluded that yield on gross loan portfolio is the most important proxy and it strongly increases the financial sustainability. This finding is in line with Yeshi (2015); Nyamsogoro (2010), and Cull et al. (2007). Further, if MFIs can increase yield while maintaining the repayment rate, those MFIs can achieve both social and institutional missions.

Write off ratio is a portion of loans removed from the gross loan portfolio (CGAP, 2003). Write-offs are part of operating expenses that are classified as bad debts because those loans will never be repaid. The write-off policy is different among the MFIs. This ratio negatively affects the financial sustainability of MFIs. The coefficient of this variable is negative (.-050) but not statistically significant (.539) even at $10 \%$ significant level. Therefore, the study can conclude that, although the write off ratio negatively affects the financial sustainability, it is not statistically significant. The study concluded that the negative coefficient could be the results of poor loan repayment, follow up policies, and wrong assessment of the clients. However this result is not in line with any literature and it is special only to Sri Lankan MFIs.

Risk coverage ratio indicated how MFIs prepare for the losses resulted from their bad debts. Usually, MFIs allocate part of their profits to cover the unpaid amount for a certain period. These amounts are known as loan loss reserves (CGAP, 2003). The longer the loan is unpaid, the higher the amount of coverage needs to be set aside to cover the loss (Nyamsogoro, 2010). The coefficient of this ratio is positive (.032) and is strongly insignificant even at $10 \%$ significant level. Hence, it can be concluded that the risk coverage ratio does not affect when determining the financial sustainability of MFIs in Sri Lanka.

Profit margin as mentioned above is the profits earned by MFIs over their revenue. 
Adoption of commercialization to microfinance organization leads to improve profits (Woller, 2000). More length in shortterm requires more profits, and this leads to a higher cost to the clients of MFIs (Navajas et al., 2000). In theory, microfinance researchers agreed that microfinance organizations focus all their efforts on commercialization and profit maximization, which automatically move them from the social mission of poverty alleviation. The econometric result of this variable is positive (.295) and is strongly statistically significant with $1 \%$ significant level. This finding was confirmed with the findings of Ayayi and Sene, (2010); and Millson (2013). The study can conclude that profit is obviously and highly influencing factor in determining the financial sustainability of MFIs in Sri Lanka. However, when compared to the average loan size it shows that MFIs satisfied the financial needs of poor clients. According to the information provided by key personalities of these organizations, they agreed that techniques like risk management, strategic financial management, consultation and monitoring their customers, etc. support to achieve their mission of poverty reduction while increasing enough profits.

MFI regulations describe the set of government rules that applied to microfinance institutions. The regulations will speed the emergence of sustainability (Arun, 2005). Microfinance regulations and financial sustainability are positively related; but Nyamsogoro (2010) stated that regulated MFIs do not perform better than unregulated ones. In Sri Lanka, the study found that $83.7 \%$ are self-regulated MFIs while the authorized body regulates $17 \%$. The econometric results indicated that the coefficient of this variable is negative (.-011) and statistically insignificant (.908). This result indicated that the regulatory mechanism negatively affected but it is not significant in determining the financial sustainability of MFIs in Sri Lanka. This finding confirms the findings by Nyamsogoro, (2010); and Mersland and Strom (2009).
Portfolio at risk is probably the most acceptable measure of portfolio quality (CGAP, 2003). The interest rate is a major income source of MFIs, and the amount of interest income to be received from the loans will depend on the quality of the loan portfolio. Therefore, the loan portfolio is one of the critical elements of MFIs affecting sustainability. CGAP (2003) defined portfolio at risk as the "outstanding amount of all loans that have one or more installments of principal past due by certain number of days." The results illustrated that portfolio risk at 30 days is negative (-.149) and statistically significant at 5\% significant level. This shows that MFIs in Sri Lanka are not efficient in making their collections and affect negatively to the sustainability. This result is confirmed by the findings of Millson (2013); and Ayayi and Sene (2010).

\section{Conclusions}

The institutionalist framework was used to test the critical determinants of sustainability of MFIs in Sri Lanka. The findings show a statistically significant positive correlation with financial sustainability of MFIs in Sri Lanka and interest rates, loan officer productivity ratio, number of active borrowers, age off MFIs, organization types, the yield on the gross loan portfolio, and the profit margin. Among these variables, the main drivers of MFIs sustainability are the loan officer productivity ratio, the age of MFIs, types of MFIs, the yield on the gross loan portfolio, and the profit margin. It was revealed that the capital structure and the operating expenses ratio strongly and negatively affected the sustainability of MFIs. These two factors are identified as major influences that decrease the financial sustainability of MFIs in Sri Lanka; whereas portfolio risks at 30 days also decrease the sustainability with $5 \%$ significant level. These positive and negative effects grounded to suggest that, targeting a higher number of clients with competitive interest rates, on average loan sizes could contribute MFIs to become more sustainable in Sri Lanka. 


\section{Implications}

The factors considered for determinacies of sustainability of MFIs in Sri Lanka were analyzed through twenty variables. There the study proposes that if MFIs in Sri Lanka strengthen their cost control methods with their operations, they will be able to achieve better sustainability. Further it suggested that, these organizations should strengthen the productivity of their staff members through occupying human resource management practices (like staff appraisal, incentives for hardworking employees, etc.). Moreover, adopting a proper monitoring system to improve loan recovery system may help them to be more sustainable. Also, it emphasizes that the MFIs need to pay more attention to financial cost management systems by adopting effective cost reductive methodologies on their operations, to improve sustainability. To do this, MFIs need to create more innovative products by adopting proper regulator mechanisms to improve outreach and sustainability. The government needs to provide an appropriate enabling environment for these organizations to do their business creatively and attractively. Notably, this will lead to attracting more potential investors to the microfinance industry.

\section{Contribution to the Knowledge}

Welfare Theory and Institutionalist Theory was used to determine the factors affecting the financial sustainability of MFIs in Sri Lanka. The study revealed that both outreach and other factors (borrower related, institutionally related, macroeconomic related, etc.) affected when determining the financial sustainability of MFIs. When considering the outreach factors, except depth and scope of outreach, all the other factors: breath (active borrower), cost (yield on gross loan portfolio), length (age and profit margin), and worth (interest rate) have simultaneous causality relationship with financial sustainability. Additionally other than the outreach related factors, loan officer productivity and organizational type also had a substantial impact on increasing financial sustainability, whereas capital structure caused a substantial decrease in financial sustainability.

\section{Contribution to Practice}

The study unveils the trade-off between financial sustainability and cost of outreach with regards to operating expenses ratio. This indicates that larger operational expenses cause a reduction in the financial sustainability of MFIs in Sri Lanka. Hence, these MFIs should go for the strategies to minimize their operational expenses such as reduce small loan administration cost, control the lending portfolio, reduce human errors etc. Also, the study ascertained that the capital structure caused a substantial decrease in financial sustainability of Sri Lankan MFIs. This is because the debt capital is larger than the equity capital of the capital structure followed by most of these MFIs. The study proposed to develop and follow strategies to decrease the debt capital. 
Perera, H.S.C., KJM, 2021, 10 (02)

\section{References}

Ahmed, I., Bhuiyan, A.B., Said, J. and Salleh, M.F.M., (2014). Breadth of Outreach and Accountability of Microfinance Institutions (Mfis) In South Asian Region. The Global Journal of Finance and Economics, 11(2), Pp.161-173.

Abdulai, A.,(2016). Performance of Microfinance Institutions in Sub-Sahara Africa: A Cross Country Analysis of Outreach, Sustainability, Efficiency and Regulation (Doctoral dissertation, University of Zululand). http://hdl.handle.net/10530/1541

Adhikary, S. and Papachristou, G., ( 2014). Is there a trade-off between financial performance and outreach in South Asian microfinance institutions?. The Journal of Developing Areas, 48(4), pp.381-402. https://www.jstor.org/stable/24241270

Arun, T. (2005). Regulations for Development: The case of Microfinance, The quarterly Review of Economics and Finance, 45,346-357. https://doi.org/10.1016/j.qref.2004.12.008

Awaworyi, S.K. and Marr, A., (2014). Sustainability and outreach: a comparative study of MFIs in South Asia and Latin America \& the Caribbean. Monash University Department of Economics Working Paper $\quad$ Series, 13 . https://www.monash.edu/business/economics/research/publications/2014/1314sustainabiltya waworyimarr.pdf

Ayayi, A.G. and Sene, M., (2010). What drives microfinance institution's financial sustainability? The Journal of Developing Areas, pp.303-324. https://www.jstor.org/stable/41428207

Bogan, V. L. (2012). Capital structure and sustainability: An empirical study of microfinance institutions. Review of Economics and Statistics, 94(4), 1045-1058. https://doi.org/10.1162/REST_a_00223

Bogan, V., Johnson, W. and Mhlanga, N., (2007). Does Capital Structure affect the financial sustainability of Microfinance Institutions? Retrieved on, 7(04), p.2013.

Brau, J. C., \& Woller, G. M. (2004). Microfinance: A comprehensive review of the existing literature. The Journal of Entrepreneurial Finance, 9(1), 1-28. . https://digitalcommons.pepperdine.edu/jef/vol9/iss1/2

CGAP.,(2009). Efficiency Drivers of MFIs; The Role of Age, Consultative Group to Assist the oor (CGAP), Brief, February available at http://www. Cgap.org/gm/document- 1.9.9338/ MIB Efficiency Brief- PDF (Accessed: July 2018).

CGAP., (2003). Microfinance Consensus Guidelines; Guiding Principles of Regulation and Supervision of Microfinance Consultative Group to Assist the Poor (CGAP), Washington, DC.

Chikaza, Z., (2015). Analysis of financial sustainability and outreach of microfinance institutions (MFIs) in Zimbabwe: case study of Harare (Doctoral dissertation, Stellenbosch: Stellenbosch University).

Cook, T. D., \& Campbell, D. T. (1979). The design and conduct of true experiments and quasiexperiments in field settings. In Reproduced in part in Research in Organizations: Issues and Controversies. Goodyear Publishing Company. 
Cull, R., Demirgu“ ç-Kunt, A., \& Morduch, J. (2007). Financial performance and outreach: A global analysis of leading microbanks. The Economic Journal, 117(517), F107-F133. https://doi.org/10.1111/j.1468-0297.2007.02017.x

Dissanayake, D. M. N. S. W. (2012). The Determinants of Microfinance Profitability: Evidences From Sri Lankan Microfinance Institutions. http://repository.kln.ac.lk/handle/123456789/13527

Dissanayake, D. (2012). The determinants of operational self-sufficiency: an empirical analysis of Sri Lankan microfinance institutions. Kelaniya Journal of Management, 1(1), 5067.

Gashayie, A. and Singh, D., (2015). Factors that Affect Financial Sustainability of Microfinance Institution: Literature Review. European Journal of Business and Management, 7(7), pp.223-225.

Greene, W.H., (2003). Econometric Analysis, Fifth International edn. New Jersey: Prentice Hall. https://link.springer.com/book/10.1007\%2F978-3-030-53953-5

Hair, J.F., Black, W.C., Babin, B.J., Anderson, R.E. and Tatham, R.L., (20060. Multivariate data analysis (Vol. 6), New Jersey.

Hermes, N., \& Lensink, R. (2011). Microfinance: its impact, outreach, and sustainability. World development, 39(6), 875-881. https://doi.org/10.1016/j.worlddev.2009.10.021

Johnson, J. and Dinardo, J., (2007). Econometric Methods, 4th International Edition, New York, McGraw-Hill

Kaur, P. (2014). Outreach and sustainability of microfinance institutions in India in pre and post Andhra Pradesh microfinance crisis in context of South Asia. Global Journal of Finance and Management, 6(6), 569-574. http://www.ripublication.com

Kereta, B. B. (2007, November). Outreach and financial performance analysis of microfinance institutions in Ethiopia. In African Economic Conference, Addis Ababa (pp. 1-31).

Khandker, S. R., Khalily, M. B., \& Khan, Z. H. (1995). Grameen Bank: performance and sustainability (Vol. 306). World Bank Publications.

Kinde, B. A. (2012). Financial sustainability of microfinance institutions (MFIs) in Ethiopia. European Journal of Business and Management, 4(15), 1-10.

Logotri. 2006, "Building sustainable microfinance system: A growth of catalyst for the poor", Local government training and research institute, society for development studies, [Online] Available: http://www.logotri.net (September 10,2011).

Marsden, J., and Nileshwar, A., 2013. Financial Inclusion and Poverty Alleviation - A Metalevel Review of Impact and Outcome Assessments of Financial Inclusion Strategies on Clients in Poverty. Microcredit Summit Campaign Washington, DC 20005, USA.

Marakkath, N. (2014). Innovative strategies devised by Indian microfinance institutions. In Global strategies in banking and finance (pp. 341-347). IGI Global. DOI: 10.4018/978-14666-4635-3.ch0

Mersland, R., \& Strøm, R. Ø. (2007). Microbanks: Ownership, performance and social tradeoffs-a global analysis. https://mpra.ub.uni-muenchen.de/id/eprint/2063 
Mersland, R. and Strøm, R.Ø., (2009). Performance and governance in microfinance institutions. Journal of Banking \& Finance, 33(4), pp.662-669.

Meyer, R. L. (2002). The demand for flexible microfinance products: lessons from Bangladesh. Journal of international development, 14(3), 351-368.

Millson, H. F. (2013). The trade-off between sustainability and outreach: the experience of commercial microfinance institutions (Doctoral dissertation). http://hdl.handle.net/10066/10992

Morduch, J. (2000). The microfinance schism. World development, 28(4), 617-629. https://doi.org/10.1016/S0305-750X(99)00151-5

Navajas, S., Schreiner, M., Meyer, R. L., Gonzalez-Vega, C., \& Rodriguez-Meza, J. (2000). Microcredit and the Poorest of the Poor: Theory and Evidence from Bolivia. World development, 28(2), 333-346. https://doi.org/10.1016/S0305-750X(99)00121-7

Nurmakhanova, M., Kretzschmar, G., \& Fedhila, H. (2015). Trade-off between financial sustainability and outreach of microfinance institutions. Eurasian Economic Review, 5(2), 231-250.

Nyamsogoro, G. D. (2010). Financial sustainability of rural microfinance institutions (MFIs) in Tanzania (Doctoral dissertation, University of Greenwich). http://gala.gre.ac.uk/id/eprint/6366

Quayes, S., ( 2012). Depth of outreach and financial sustainability of microfinance institutions. Applied Economics, 44(26), pp.3421-3433.

Quayes, S. (2015). Outreach and performance of microfinance institutions: a panel analysis. Applied Economics, 47(18), 1909-1925. https://doi.org/10.1080/00036846.2014.1002891

Rai, A.K. and Rai, S., (2012). Factors affecting financial sustainability of microfinance institutions. Journal of Economics and Sustainable Development, 3(6), pp.1-9.

Rao, K. R. M., \& Fitamo, T. L. (2015). Concepts and Measures of Outreach and Sustainability in Microfinance Institutions (A Comprehensive Literature Review). International Journal of Science and Research (IJSR), 4(2).

Sathye, M., Mukhopadhyay, B., \& Sathye, S. (2014). Sustainability and outreach in microfinance institutions in India: an ethical analysis. Canadian Journal of Development Studies/Revue canadienne d'études du développement, 35(3), 358-375. https://doi.org/10.1080/02255189.2014.936835

Schreiner, M.,(2000).Credit scoring for microfinance: Can it work?. Journal of Microfinance/ESR Review, 2(2), p.6.

Schreiner, M. (2002). Aspects of outreach: A framework for discussion of the social benefits of microfinance. Journal of international development, 14(5), 591-603. https://doi.org/10.1002/jid.908

Tehulu, T. A. (2013). Determinants of financial sustainability of microfinance institutions in East Africa. European Journal of Business and Management, 5(17), 152-158. https://core.ac.uk/download/pdf/234624875.pdf 
Perera, H.S.C., KJM, 2021, 10 (02)

Thrikawala, S. (2017). Does gender diversity influence the operational sustainability of microfinance institutions (MFIS) in Sri Lanka. Journal of Business and Technology, 5(2), 65 83.

Woller, G., (2000). Efficiency in Microfinance Institutions. Microbanking Bulletin, 4, pp.38.

Woller, G. M., Dunford, C., \& Woodworth, W. (1999). Where to microfinance. International Journal of Economic Development, 1(1), 29-64.

Yeshi, A. (2015). The Relationship between Outreach and Financial Sustainability: An Empirical Study on Ethiopian Microfinance Institutions. Master's Degree Thesis. Addis Ababa University.

\section{Appendices}

\section{Appendix A}

Table 01: Variable Description Independent Variable for Determinants of Financial Sustainability

\begin{tabular}{|c|c|c|c|c|}
\hline $\begin{array}{l}\text { Variable } \\
\text { Standard } \\
\text { Name }\end{array}$ & Variable Description & $\begin{array}{l}\text { Variable } \\
\text { Name in } \\
\text { Regression } \\
\text { Model }\end{array}$ & $\begin{array}{l}\text { Measurement } \\
\text { as used in } \\
\text { Regression } \\
\text { Model }\end{array}$ & References \\
\hline $\begin{array}{l}\text { Financial } \\
\text { Self } \\
\text { Sufficiency } \\
\text { (FSS) }\end{array}$ & $\begin{array}{l}\text { Financial } \\
\text { Sustainability also is } \\
\text { known as financial } \\
\text { self-sufficiency and it } \\
\text { refers to the ability of } \\
\text { an MFI to cover all its } \\
\text { costs from its own } \\
\text { generated income } \\
\text { from MFI's operations } \\
\text { without depending } \\
\text { external supports }\end{array}$ & FSS & $\begin{array}{l}\text { Adjusted } \\
\text { Financial } \\
\text { Revenue / } \\
\text { (Operating } \\
\text { Expenses } \\
+ \text { +Financial } \\
\text { Expenses + } \\
\text { Loan Loss } \\
\text { Provisions } \\
\text { Expenses + } \\
\text { Expenses } \\
\text { Adjustments) }\end{array}$ & $\begin{array}{l}\text { (Nyamsogoro, } \\
(2010)\end{array}$ \\
\hline $\begin{array}{l}\text { Capital } \\
\text { Structure }\end{array}$ & $\begin{array}{l}\text { Various sources of } \\
\text { funds making up the } \\
\text { capital structure of } \\
\text { MFIs }\end{array}$ & Capstruc & $\begin{array}{l}\text { Natural log of } \\
\text { Equity as a } \\
\text { percentage of } \\
\text { total capital } \\
\text { (Equity/ } \\
\text { Assets) }\end{array}$ & $\begin{array}{l}\text { Nyamsogoro } \\
(2010), \text { Bogan } \\
\text { et al. }(2007)\end{array}$ \\
\hline
\end{tabular}


Perera, H.S.C., KJM, 2021, 10 (02)

\begin{tabular}{|c|c|c|c|c|}
\hline Interest Rate & $\begin{array}{l}\text { The rate of the interest } \\
\text { charge on an } \\
\text { outstanding loan }\end{array}$ & Intrate & $\begin{array}{l}\text { The rate of } \\
\text { interest charge }\end{array}$ & $\begin{array}{l}\text { CGAP } \\
(2003), \\
\text { Ayai and Sene } \\
(2010)\end{array}$ \\
\hline $\begin{array}{l}\text { Average } \\
\text { Loan Size }\end{array}$ & $\begin{array}{l}\text { Ratio of outstanding } \\
\text { loan portfolio over the } \\
\text { number of active } \\
\text { borrowers }\end{array}$ & Aveloans & $\begin{array}{l}\text { Natural Log of } \\
\text { average loan } \\
\text { size }\end{array}$ & $\begin{array}{l}\text { Nyamsogoro } \\
(2010), \\
\text { CGAP (2003) }\end{array}$ \\
\hline $\begin{array}{l}\text { Loan Officer } \\
\text { Productivity } \\
\text { Ratio }\end{array}$ & $\begin{array}{l}\text { The ratio of the } \\
\text { number of active } \\
\text { borrowers over the } \\
\text { number of total loan } \\
\text { officers. }\end{array}$ & Loanofiprodu & $\begin{array}{l}\text { The ratio of } \\
\text { active } \\
\text { borrowers to } \\
\text { the loan officer }\end{array}$ & $\begin{array}{l}\text { CGAP (2003) } \\
\text { Chikaza } \\
(2015) \text { and } \\
\text { Ayayi and } \\
\text { Sene (2010) }\end{array}$ \\
\hline $\begin{array}{l}\text { Active } \\
\text { Borrowers }\end{array}$ & $\begin{array}{l}\text { Number of } \\
\text { individuals who are } \\
\text { currently and actively } \\
\text { have a loan balance } \\
\text { with MFIs }\end{array}$ & actborrowers & $\begin{array}{l}\text { Natural } \log \text { of } \\
\text { the number of } \\
\text { active } \\
\text { borrowers }\end{array}$ & $\begin{array}{l}\text { Ayayi and } \\
\text { Sene (2010), } \\
\text { CGAP (2003) }\end{array}$ \\
\hline $\begin{array}{l}\text { Percentage } \\
\text { of Female } \\
\text { borrowers }\end{array}$ & $\begin{array}{l}\text { Percentage of female } \\
\text { clients served by MFI }\end{array}$ & Femaleborrw & $\begin{array}{l}\text { Percentage of } \\
\text { female clients } \\
\text { served by MFI }\end{array}$ & $\begin{array}{l}\text { Nyamsogoro, } \\
(2010)\end{array}$ \\
\hline MFI Age & $\begin{array}{l}\text { The length of } \\
\text { outreach or number of } \\
\text { years served since } \\
\text { MFI established }\end{array}$ & Mfiage & $\begin{array}{l}\text { Natural log of } \\
\text { age of MFI }\end{array}$ & $\begin{array}{l}\text { Cull et al. } \\
(2007) \text {, } \\
\text { CGAP (2009) }\end{array}$ \\
\hline MFI Size & $\begin{array}{l}\text { The value of assets of } \\
\text { MFI }\end{array}$ & Mfisize & $\begin{array}{l}\text { Total assets of } \\
\text { MFIs }\end{array}$ & $\begin{array}{l}\text { Mersland and } \\
\text { Strom (2009) }\end{array}$ \\
\hline $\begin{array}{l}\text { Portfolio at } \\
\text { risk } 30 \text { days }\end{array}$ & $\begin{array}{l}\text { Portfolio risk into } \\
\text { days over MFI gross } \\
\text { loan portfolio }\end{array}$ & Portforisk & 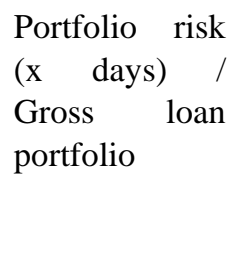 & $\begin{array}{l}\text { CGAP } \\
(2003), \\
\text { Nyamsogoro } \\
(2010)\end{array}$ \\
\hline
\end{tabular}


Perera, H.S.C., KJM, 2021, 10 (02)

\begin{tabular}{|c|c|c|c|c|}
\hline $\begin{array}{l}\text { Cost per } \\
\text { borrower }\end{array}$ & $\begin{array}{l}\text { Operating expenses } \\
\text { over MFI's average } \\
\text { number of active } \\
\text { borrowers }\end{array}$ & Costpeborrow & $\begin{array}{l}\text { Operating } \\
\text { expense } \\
\text { Average } \\
\text { number } \\
\text { active } \\
\text { borrowers }\end{array}$ & $\begin{array}{l}\text { CGAP } \\
(2003), \\
\text { Nyamsogoro } \\
(2010)\end{array}$ \\
\hline Type of MFI & $\begin{array}{l}\text { Ownership type of the } \\
\text { MFI }\end{array}$ & mfitype & $\begin{array}{l}\text { 1=Guaranteed } \\
\text { Ltd 2=NGO } \\
\text { 3=Limited } \\
\text { liability } \\
\text { company } \\
\text { 4=Org under } \\
\text { Gov } \\
\text { supervision } \\
\text { 5=Private } \\
\text { Company } \\
\text { 6=Public } \\
\text { limited } \\
\text { 7=Non- } \\
\text { Banking } \\
\text { 8= Licensed } \\
\text { Specialized } \\
\text { Bank } \\
\text { 9=Cooperative }\end{array}$ & $\begin{array}{l}\text { Mersland and } \\
\text { Strom (2009), } \\
\text { Nyamsogoro } \\
(2010)\end{array}$ \\
\hline $\begin{array}{l}\text { MFI } \\
\text { Products }\end{array}$ & $\begin{array}{l}\text { Types of products } \\
\text { offered by MFI }\end{array}$ & mfiproducts & $\begin{array}{l}1 \text { =Loans } \\
\text { 2=Loan } \\
\text { \&savings } \\
\text { 3=Loan, } \\
\text { Savings and } \\
\text { other Services }\end{array}$ & $\begin{array}{l}\text { Chikaza, } \\
(2015)\end{array}$ \\
\hline $\begin{array}{l}\text { Lending } \\
\text { methodology }\end{array}$ & $\begin{array}{l}\text { Type of lending } \\
\text { methodology offered } \\
\text { by MFI }\end{array}$ & mfilenmeth & $\begin{array}{l}\text { Type 1-5 of } \\
\text { lending coded } \\
\text { where 1= } \\
\text { Individual } \\
\text { lending } \\
\text { through } \\
\text { clusters, } 2= \\
\text { Individual } \\
\text { based } \\
\text { solidarity on } \\
\text { groups, } 3=\end{array}$ & $\begin{array}{l}\text { Mersland and } \\
\text { Strom (2009), } \\
\text { Nyamsogoro } \\
(2010)\end{array}$ \\
\hline
\end{tabular}




\begin{tabular}{|c|c|c|c|c|}
\hline & & & $\begin{array}{l}\text { Individual } \\
\text { loans, } 4= \\
\text { Individual } \\
\text { loans through } \\
\text { CBO, 5=Both } \\
\text { group and } \\
\text { individual } \\
\text { lending }\end{array}$ & \\
\hline $\begin{array}{l}\text { MFI } \\
\text { geography } \\
\text { location } \\
\text { served }\end{array}$ & $\begin{array}{l}\text { Geographical } \\
\text { locations of an MFI } \\
\text { served }\end{array}$ & mfigeoloc & $\begin{array}{l}\text { Dummy } \\
\text { variable } 1 \text { if } \\
\text { MFI served in } \\
\text { rural areas if } \\
\text { not } 0\end{array}$ & $\begin{array}{l}\text { Nyamsogoro, } \\
(2010)\end{array}$ \\
\hline $\begin{array}{l}\text { Operating } \\
\text { expenses } \\
\text { ratio }\end{array}$ & $\begin{array}{l}\text { Operating expenses } \\
\text { over loan portfolio }\end{array}$ & operaexratio & $\begin{array}{l}\text { Natural log of } \\
\text { operating } \\
\text { expenses ratio } \\
\text { or Operating } \\
\text { expenses / by } \\
\text { loan portfolio }\end{array}$ & $\begin{array}{l}\text { CGAP, } \\
(2003)\end{array}$ \\
\hline $\begin{array}{l}\text { Yield on } \\
\text { gross } \\
\text { portfolio }\end{array}$ & \begin{tabular}{lrr} 
Cash & \multicolumn{2}{c}{ financial } \\
revenue & from & loan \\
portfolio & over & MFI \\
average & gross & loan \\
portfolio & &
\end{tabular} & yieongrpolio & $\begin{array}{l}\text { Yield on gross } \\
\text { loan portfolio }\end{array}$ & $\begin{array}{l}\text { CGAP } \\
(2003), \\
\text { Nyamsogoro } \\
(2010)\end{array}$ \\
\hline $\begin{array}{l}\text { Write- off } \\
\text { Ratio }\end{array}$ & $\begin{array}{lcc}\text { Values } & \text { of } & \text { loans } \\
\text { written- } & \text { off } & \text { over } \\
\text { average } & \text { gross } & \text { loan } \\
\text { portfolio } & & \end{array}$ & wriofratio & $\begin{array}{l}\text { Value of loans } \\
\text { written off / } \\
\text { average gross } \\
\text { loan portfolio }\end{array}$ & CGAP (2003) \\
\hline $\begin{array}{l}\text { Risk } \\
\text { coverage } \\
\text { Ratio }\end{array}$ & $\begin{array}{l}\text { Loan loss revenue } \\
\text { over portfolio at risk } \\
\text { for } 30 \text { days }\end{array}$ & riskcovratio & $\begin{array}{l}\text { Loan loss } \\
\text { revenue } \\
\text { Portfolio risk } \\
\text { for } 30 \text { days }\end{array}$ & $\begin{array}{l}\text { CGAP } \\
(2003), \\
\text { Nyamsogoro } \\
(2010)\end{array}$ \\
\hline $\begin{array}{l}\text { MFI } \\
\text { Regulation }\end{array}$ & $\begin{array}{l}\text { Status of } \\
\text { Microfinance } \\
\text { regulations }\end{array}$ & mfireg & $\begin{array}{l}1=\text { Self- } \\
\text { regulated } \\
2=\text { Regulated } \\
\text { by the }\end{array}$ & \\
\hline
\end{tabular}


Perera, H.S.C., KJM, 2021, 10 (02)

\begin{tabular}{|l|l|l|l|l|}
\hline & & & $\begin{array}{l}\text { authorized } \\
\text { body }\end{array}$ & $\begin{array}{l}\text { CGAP } \\
(2003), \text { Arun } \\
(2005)\end{array}$ \\
\hline $\begin{array}{l}\text { Profit } \\
\text { Margin }\end{array}$ & $\begin{array}{l}\text { Profit of MFI over } \\
\text { their revenue }\end{array}$ & profmarg & $\begin{array}{l}\text { Natural log of } \\
\text { Profit margin } \\
\text { of MFI }\end{array}$ & $\begin{array}{l}\text { Ayayi and } \\
\text { Sene (2010) }\end{array}$ \\
\hline
\end{tabular}

Source: Develop by Researcher 2019

\section{Appendix B}

Table 02: Descriptive Results FSS in MFI Sri Lanka

\begin{tabular}{|l|r|r|r|r|c|}
\hline \multirow{2}{*}{ Variables } & \multicolumn{1}{|c|}{$\mathrm{N}$} & Minimum & Maximum & Mean & Std. Deviation \\
\cline { 2 - 6 } & \multicolumn{1}{|c|}{ Statistic } & \multicolumn{1}{c|}{ Statistic } & \multicolumn{1}{c|}{ Statistic } & Statistic & Statistic \\
\hline FSS & 204 & .575 & 2.875 & 1.199527 & .2889168 \\
\hline
\end{tabular}

Source: Develop by Researcher 2019 


\section{Appendix C}

Table 03: Descriptive Statistics of Independent Variables Affected to Financial Sustainability

\begin{tabular}{|c|c|c|c|}
\hline Variables in Model "b" & Mean & Std. Deviation & $\mathrm{N}$ \\
\hline FSS & 1.199527 & .2889168 & 204 \\
\hline Capital structure & .380934 & .2660986 & 204 \\
\hline Interest rate & .201995 & .0586307 & 204 \\
\hline Average loan size & 23998.38 & 13704.695 & 204 \\
\hline Loan officer productivity ratio & 316.03 & 213.800 & 204 \\
\hline Number of active borrowers & 44080 & 147460 & 204 \\
\hline Percentage of female borrowers & .842458 & .1727135 & 204 \\
\hline Age & 17.2 & 8.942 & 204 \\
\hline MFI size & 2557131676.82 & 10729124439.4 & 204 \\
\hline Cost per borrower & 6854.46 & 10805.928 & 204 \\
\hline Organization types & 3.03 & 2.220 & 204 \\
\hline No of MFIs products & 2.43 & .871 & 204 \\
\hline MFIs lending methodology & 2.86 & .912 & 204 \\
\hline No of MFI geographic location & 7.00 & 8.248 & 204 \\
\hline Operating expenses ratio & .28188 & .205056 & 204 \\
\hline $\begin{array}{l}\text { The yield on gross portfolio } \\
\text { (Real) }\end{array}$ & .177702 & .1026851 & 204 \\
\hline Write-off ratio & .020588 & .0382847 & 204 \\
\hline Risk coverage ratio & .201417 & .3393111 & 204 \\
\hline Profit margin & .30287 & .34121 & 204 \\
\hline MFI regulations & 1.17 & .378 & 204 \\
\hline Portfolio risk at 30 days & .10113 & .132551 & 204 \\
\hline
\end{tabular}




\section{Appendix D}

Table 04: Model Summary of Model "b"

\begin{tabular}{|l|l|l|l|l|}
\hline Model "b" & $\mathrm{R}$ & R Square & $\begin{array}{l}\text { Adjusted R } \\
\text { Square }\end{array}$ & $\begin{array}{l}\text { Std Error of the } \\
\text { Estimate }\end{array}$ \\
\hline 1 & $.692^{\mathrm{a}}$ & .479 & .419 & .2201417 \\
\hline
\end{tabular}

Source: Survey Results 2019

a. Predictors: (Constant), Percentage of female managers, Yield on gross portfolio (Real), Average Loan Size, Risk coverage ratio, Write-off ratio, capital structure, Cost per borrower, Interest Rate, No of MFIs products, Portfolio risk at 30 days, MFI size, Percentage of female borrowers, MFIs lending methodology, Operating expenses ratio, Organization types, Loan officer productivity ratio, No of MFI geographic location, profit margin, MFI regulations, age, borrowers

\section{Appendix E}

Table 05: Model Fitness

\begin{tabular}{|c|c|c|c|c|c|c|}
\hline \multicolumn{2}{|c|}{ Model } & Sum of Squares & $\mathrm{df}$ & $\begin{array}{l}\text { Mean } \\
\text { Square }\end{array}$ & $\mathrm{F}$ & Sig. \\
\hline \multirow{3}{*}{1} & Regression & 8.125 & 21 & \multirow{3}{*}{$\begin{array}{l}.387 \\
.048\end{array}$} & \multirow[t]{3}{*}{7.983} & \multirow[t]{3}{*}{$.000^{\mathrm{b}}$} \\
\hline & Residual & 8.820 & 182 & & & \\
\hline & Total & 16.945 & 203 & & & \\
\hline
\end{tabular}

Source: Survey Results 2019

a. Dependent Variable: FSS

b. Predictors: (Constant), Percentage of female managers, Yield on gross portfolio (Real), Average Loan Size, Risk coverage ratio, Write-off ratio, lncs, Cost per borrower, Interest Rate, No of MFIs products, Portfolio risk at 30 days, MFI size, Percentage of female borrowers, MFIs lending methodology, Operating expenses ratio, Organization types, Loan officer productivity ratio, No of MFI geographic location, lnprofitmargin, MFI regulations, lnage, lnborrowers 
Perera, H.S.C., KJM, 2021, 10 (02)

\section{Appendix F}

Table 06: Econometric Results of the Determinants of Financial Sustainability Coefficients a

\begin{tabular}{|c|c|c|c|c|c|c|c|}
\hline \multirow[t]{2}{*}{ Model "b" } & \multicolumn{2}{|c|}{$\begin{array}{c}\text { Unstandardized } \\
\text { Coefficients }\end{array}$} & \multirow{2}{*}{\begin{tabular}{|c|}
$\begin{array}{c}\text { Standardized } \\
\text { Coefficient }\end{array}$ \\
Beta
\end{tabular}} & \multirow[t]{2}{*}{$t$} & \multirow[t]{2}{*}{ Sig. } & \multicolumn{2}{|c|}{$\begin{array}{c}\text { Co-linearity } \\
\text { Statistics }\end{array}$} \\
\hline & B & $\begin{array}{l}\text { Std. } \\
\text { Error }\end{array}$ & & & & Tolerance & VIF \\
\hline (Constant) & .325 & .287 & & 1.131 & .259 & & \\
\hline Incapitalstructure & -.093 & .020 & -.331 & 4.701 & $.000 * * *$ & .577 & 1.732 \\
\hline Interest Rate & .757 & .350 & .154 & 2.160 & $.032 * *$ & .566 & 1.768 \\
\hline Average Loan Size & $\begin{array}{r}5.224 \mathrm{E}- \\
007 \\
\end{array}$ & .000 & .025 & .364 & .717 & .616 & 1.623 \\
\hline $\begin{array}{l}\text { Loan officer prode } \\
\text { ratio }\end{array}$ & .000 & .000 & .230 & 3.077 & $.002 * * *$ & .512 & 1.954 \\
\hline Inborrowers & .007 & .017 & .151 & .417 & $.077 *$ & .194 & 5.150 \\
\hline female borrowers & .211 & .026 & .126 & 1.736 & .684 & .543 & 1.841 \\
\hline Inage & .130 & .044 & .277 & 2.934 & $.004 * * *$ & .322 & 3.105 \\
\hline MFI size & $\begin{array}{r}1.840 \mathrm{E}- \\
012 \\
\end{array}$ & .000 & .068 & .788 & .432 & .381 & 2.627 \\
\hline Cost per borrower & $\begin{array}{r}3.472 \mathrm{E}^{-} \\
007 \\
\end{array}$ & .000 & -.013 & -.202 & .840 & .689 & 1.451 \\
\hline Organization types & .029 & .011 & .221 & 2.623 & $.009 * * *$ & .401 & 2.493 \\
\hline No of MFIs products & .010 & .022 & .030 & .433 & .658 & .794 & 1.252 \\
\hline $\begin{array}{l}\text { MFIs lending } \\
\text { method }\end{array}$ & .020 & .029 & .064 & .697 & .486 & .341 & 2.928 \\
\hline MFI geo location & .002 & .005 & .035 & .379 & .705 & .395 & 2.534 \\
\hline $\begin{array}{l}\text { Operating expense } \\
\text { ratio }\end{array}$ & -.662 & .112 & -.470 & $5.886^{-}$ & $.000 * * *$ & .449 & 2.226 \\
\hline $\begin{array}{l}\text { Yield on gross } \\
\text { portfolio }\end{array}$ & .698 & .196 & .248 & 3.560 & $.000 * * *$ & .589 & 1.698 \\
\hline Write-off ratio & -.380 & .617 & -.050 & -.616 & .539 & .428 & 2.335 \\
\hline
\end{tabular}


Perera, H.S.C., KJM, 2021, 10 (02)

\begin{tabular}{||l|r|r|r|r|l|r|r|}
\hline Risk coverage ratio & .027 & .092 & .032 & .297 & .767 & .244 & 4.090 \\
\hline Inprofitmargin & .064 & .018 & .295 & 3.519 & $.001 * * *$ & .407 & 2.458 \\
\hline MFI regulations & -.008 & .070 & -.011 & -.116 & .908 & .345 & 2.899 \\
\hline $\begin{array}{l}\text { Portfolio risk at } 30 \\
\text { days }\end{array}$ & -.325 & .142 & -.149 & - & $.023 * *$ & .678 & 1.475 \\
\hline $\begin{array}{l}\text { Source: Survey Results } 2019 \\
\text { a. Dependent Variable: FSS }\end{array}$ & $* * 1 \%$ Significant $* * 5 \%$ Significant * $10 \%$ Significant \\
\hline
\end{tabular}

